\title{
Particle formation in the planetary boundary layer over Tokyo and its suburban areas
}

\author{
H. Minoura ${ }^{1,2}$ \\ ${ }^{1}$ Toyota Motor Engineering \& Manufacturing North America, USA \\ ${ }^{2}$ Toyota Central R\&D Labs. Inc., Japan
}

\begin{abstract}
The Japanese Ministry of the Environment promulgated the new air quality standard of $\mathrm{PM}_{2.5}$ in September, 2009, which is equal to the value of the air quality standards of the US EPA (yearly average $15 \mu \mathrm{g} \mathrm{m} \mathrm{m}^{-3}$ and $24 \mathrm{~h}$ average $35 \mu \mathrm{g} \mathrm{m}{ }^{-3}$ ). With the concentration of primary particles such as elemental carbon decreasing during the last decade, the contribution of secondary particles became a big concern. Observation using an aircraft is advantageous in that observation over the city sky does not receive local exhaust influence, is able to cover a wide range at a time, and is useful in understanding spatial character of the secondary particles.

With the aircraft, a spatial variation of the particle size distribution $(0.5-$ $10 \mu \mathrm{m})$ of the coast line area and the inland area was measured nine times in three days from July 30, 2008 over the South Kanto region including the Tokyo metropolitan area. From the level flight observation at $600 \mathrm{~m}$ altitude, the increased tendency of particle number concentration and the decreased tendency of mean particle diameter were observed as we flew to the north inland area. The number concentration and the relationship with the mean particle diameter showed the well-organized distribution. A volumetric change of more than 3 times was seen in the distribution of particles sampled in the inland area, whereas, a clear volumetric change was not seen in the distribution of particles sampled on the coast line. As for the number concentration of the particle, the mean particle diameter, and the particle volume, the value changed at the rate of $0.74 \mathrm{~cm}^{-3} \mathrm{~km}^{-1},-0.48 \mathrm{~nm} \mathrm{~km}^{-1}, 0.057 \mu \mathrm{m}^{3} \mathrm{~cm}^{-3} \mathrm{~km}^{-1}$ each as a function of distance from the coast line. The increment tendency of the volume growth rates was seen in proportion to the $\mathrm{NO}_{2}$ concentration in particular.
\end{abstract}

Keywords: Japan, Tokyo, spatial distribution, particulate matter, particle number concentration, secondary particle. 


\section{Introduction}

Atmospheric particulate matter (PM) is important for health, visibility, and climate [1-3]. The Japanese Ministry of the Environment promulgated the new air quality standard of $\mathrm{PM}_{2.5}$ in September, 2009, and this leads a public interest in air quality improvement. The values were equal to the air quality standard of the US EPA (24-hour-average is $35 \mu \mathrm{g} \mathrm{m}^{-3}$ and yearly average is $15 \mu \mathrm{g} \mathrm{m}^{-3}$ ). However, because the annual average concentration of $\mathrm{PM}_{2.5}$ in the remote area with very little anthropogenic emission shows the value close to the air quality standard, it seems to be difficult to achieve the standard in an urban area. The elemental carbon (EC) concentration that was a representative of the primary particle in $\mathrm{PM}_{2.5}$ decreased in Tokyo conspicuously, on the other hand, the contribution of the secondary particle such as sulfate and organic carbon (OC) has been a big concern till now [4]. As for the sulfate, Aikawa et al. [5] pointed out that there is $50-70 \%$ of influence by long-distance transportation from China. However, the quantity that $\mathrm{OC}$ based on the organic gas from regional sources contributes to secondary particle of $\mathrm{PM}_{2.5}$ is big [6-9].

Since a secondary particle comes to occupy a main body of $\mathrm{PM}_{2.5}$ in Japan, it is necessary to understand the formation process of the secondary particle. In order to characterize chemical components of particle matter (PM), it is necessary to observe for a long time over the wide area. When we collect samples using PM sampler, we must consider influence of the neighboring exhaust emission such as small stacks or industrial facilities. Moreover, it is ideal to collect a particle in places as much as possible at the same time to understand the spatial distribution of the components. Observation using an aircraft is advantageous in that the observation over the city sky does not receive neighboring exhaust influence at the same time to be able to cover a wide range at a time. From this reason, the aircraft observation is useful in understanding spatial character of the secondary particle.

As for the research of nucleation and the secondary particle formation of the particle, much research has been accomplished till now, Kulmala et al. [10] reported a review of formation and growth rates of ultrafine atmospheric particles including research of urban atmosphere. Those studies are based on the size variation of ultrafine particle. However, there are many observation reports which show high concentration of secondary particles in suburban area when we measure on the basis of mass to compare with urban area. The mass growth is observed in fine particle size range, not ultrafine particle size range.

If vehicle exhaust is a large contributor to $\mathrm{PM}_{2.5}$ in Japan, it is expected that $\mathrm{PM}_{2.5}$ levels would decrease as emission control take effect in the vehicle fleet. To evaluate the effective improvement in $\mathrm{PM}_{2.5}$ concentration, the Ministry of Economy, Trade and Industry started the JATOP (Japanese Auto-Oil program; www.pecj.or.jp/english/jcap/index_e.asp) in 2007 to investigate the influence that motor vehicle emission gave on ambient PM. During this program, two big observation campaigns were carried out in the summer of 2008 and the winter of 2009. This research is the results of the summer observation campaign. 


\section{Observation}

Figure 1 shows the location of the flight course and the meteorological observation sites. Table 1 summarizes the measurements items. The aircraft with five-passenger helicopter (AS355F2, Aérospatiale Inc., France) was used, and the observation items shown in Table 1 were recorded every one second. Ambient air was introduced to the Aerodynamic Particle Sizer (APS) Spectrometer, and the NOx and the $\mathrm{O}_{3}$ monitor. The location and the high level of the aircraft were monitored with the GPS system. The correction of the NOx monitor and the $\mathrm{O}_{3}$ monitor was carried out before and after each flight using standard gases.

We started the Tokyo heliport and made a round trip to Urayasu at $200 \mathrm{~m}$ altitude. Then, we made a round trip to Kisai via Saitama University, which belongs to the South Kanto inland area at $600 \mathrm{~m}$ altitude. We kept the mean flying speed $60 \mathrm{~km} \mathrm{hr}^{-1}$. This level flight was conducted nine times in three days from July 30 to August 1, 2008.

Table 1: $\quad$ Summary of observation instruments.

\begin{tabular}{|c|c|c|c|c|}
\hline & Observables & Instruments & Measurement Method & Detection limit \\
\hline \multirow{4}{*}{$\begin{array}{l}\text { Aircraft } \\
\text { observation }\end{array}$} & $\begin{array}{l}\text { PM number concentration and } \\
\text { diameter }(0.5-20 \mu \mathrm{m})\end{array}$ & TSI, APS model 3321 & Time-of-flight & 0.001 particle $/ \mathrm{cm}^{3}$ \\
\hline & $\mathrm{NO}, \mathrm{NO}_{2}$ & $\begin{array}{c}\text { Thermo Fisher Scientific, } \\
\text { Model } 42 \mathrm{C} / \mathrm{J} \\
\end{array}$ & Chemiluminescence & $0.40 \mathrm{ppb}$ \\
\hline & $\mathrm{O}_{3}$ & Dylec, Model 1150 & \begin{tabular}{|l|} 
Ultraviolet absorption \\
\end{tabular} & $1 \mathrm{ppb}$ \\
\hline & $\begin{array}{l}\text { Location, altitude, and travelling } \\
\text { speed }\end{array}$ & Garmin Oregon300 & \begin{tabular}{c|} 
GPS (Ground \\
positioning systems)
\end{tabular} & $10 \mathrm{~m}$ \\
\hline $\begin{array}{l}\text { Rawinsonde } \\
\text { observation }\end{array}$ & $\begin{array}{c}\text { Vertical distribution of wind velocity, } \\
\text { wind direction, temperature, and } \\
\text { humidity }\end{array}$ & $\begin{array}{l}\text { Japan Weather } \\
\text { Association, } \\
\text { JWA94W/RD80H }\end{array}$ & $\begin{array}{l}\text { Semiconductor } \\
\text { temperature } \\
\text { hygrometer }\end{array}$ & $\begin{array}{c} \pm 0.1 \mathrm{deg} . \\
\pm 5 \% \mathrm{RH} \\
\text { wind speed: } 1 \mathrm{~m} / \mathrm{s}\end{array}$ \\
\hline \multirow{4}{*}{$\begin{array}{l}\text { Ground base } \\
\text { observation }\end{array}$} & Wind velocity and wind direction & Kaijo, DA-600 & Ultrasonic anemometer & $0.005 \mathrm{~m} / \mathrm{s}$ \\
\hline & Temperature & Chino, Pt-100 & $\begin{array}{c}\text { Platinum resistance } \\
\text { thermometer }\end{array}$ & $\pm 0.3 \mathrm{deg}$ \\
\hline & Relative humidity & Vaisala, HMP-45A & HUMICAP180 sensor & $\pm 2 \%$ \\
\hline & Solar radiation intensity & Eko, MS-402F & Pyrheliometer & $\pm 0.5 \%$ \\
\hline
\end{tabular}

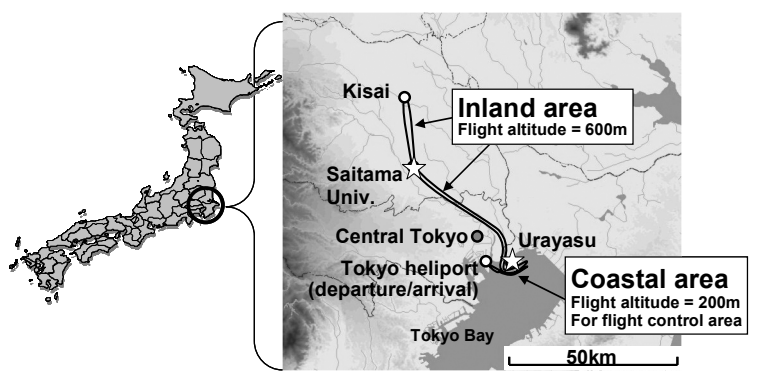

Figure 1: Location of the meteorological observation sites and the flight course. The rawinsonde observation was carried out at the sites of star. 
A rawinsonde was launched from the Urayasu and the Saitama University sites every three hours for four days including the aircraft observation period to measure the vertical distributions of wind direction, wind speed, temperature and relative humidity. During this flight, ground-base observation was conducted at Urayasu (the Tokyo bay area), downtown Tokyo, Saitama University (a suburban area), and Kisai (a rural area).

\section{Results}

\subsection{Wind conditions}

Figure 2 shows the backward trajectory analysis results of air parcel arriving at each sites of South Kanto region. This trajectory analysis was obtained from wind data of more than 200 monitoring sites adjusted to $10 \mathrm{~m}$ high level by using the method of inverse root-squaring of the distance. The trajectory line shows the air parcel movement of 24 hours. It is shown that an air parcel was transported from the east at most sites in South Kanto region. The mean wind velocity and the mean wind direction from July 30 to August 1 were $1.6,1.1,1.0 \mathrm{~m} \mathrm{~s}^{-1}$ and 58 , 82,153 degrees each. Because the objective analysis data was limited for time and space in comparison with above monitoring data, the method mentioned above can expect high precision by a short time period and the near ground level analysis. For confirmation, we check the trajectory of each air parcel arriving at $600 \mathrm{~m}$ altitude by using the HYSPLIT model as a reference, and obtained similar results. The result that wind direction was almost an easterly wind in the whole South Kanto area means that the direction of the wind was almost perpendicular to the flight course to the inland part during the observation period, and we could observe PM and trace gases without following the same air parcel. This observation was carried out while a condition of ideal wind direction lasted three days as mentioned above.

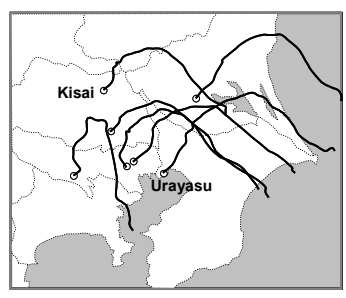

2008/7/30 9:00

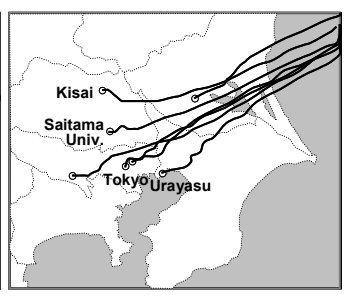

2008/7/31 9:00

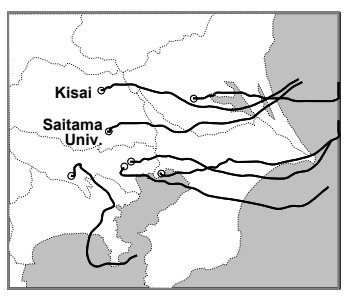

2008/8/1 9:00

Figure 2: $\quad$ Backward trajectories of air parcel arrived at the time written under the figure (the trajectory length shows the trace for 24 hours).

\subsection{The vertical distribution of pollutants}

The vertical distribution of pollutants was observed at Saitama University and Kisai. The vertical distribution between $300 \mathrm{~m}$ and $600 \mathrm{~m}$ showed approximately 
constant for each pollutant. From the rawinsonde observation, all flights of this time having been in the planetary boundary layer (PBL), constant concentration of pollutants in the PBL agreed with the result of Laaksonen et al. [11].

Because the particle number (PN) concentration measured using the APS Spectrometer targets $0.5 \mu \mathrm{m}$ or more, the ultrafine particle less than $100 \mathrm{~nm}$ is not included. Wang et al. [12] measured vertical variation of the particle size distribution including the ultrafine particle from an altitude of $400 \mathrm{~m}$ to $2,400 \mathrm{~m}$ during dust storm using the EEPS (engine exhaust particle sizer). And they found that nucleation mode particle excelled at high altitude more than PBL, although accumulation mode particle was dominant in low altitude. As far as we looked in the range of fine particle and more, particle number concentration in Kisai was slightly higher. In spite of temporal variation of pollutant concentrations, the vertical distribution was uniform.

\subsection{The horizontal variation of pollutants}

An example of the variation of particle size distribution seen in level flight is shown in Figure 3 as a spatial variation of number concentration and mean particle diameter. The result of Figure 3 was provided in flight from 15:35 to 16:52 on July 31, 2008 and the average altitude was $619 \mathrm{~m}(590-667 \mathrm{~m})$. The increased tendency of PN concentration and the decreased tendency of mean particle diameter (PD) were observed as we flew to north (deep inland area). The similar tendency was seen in other flights.
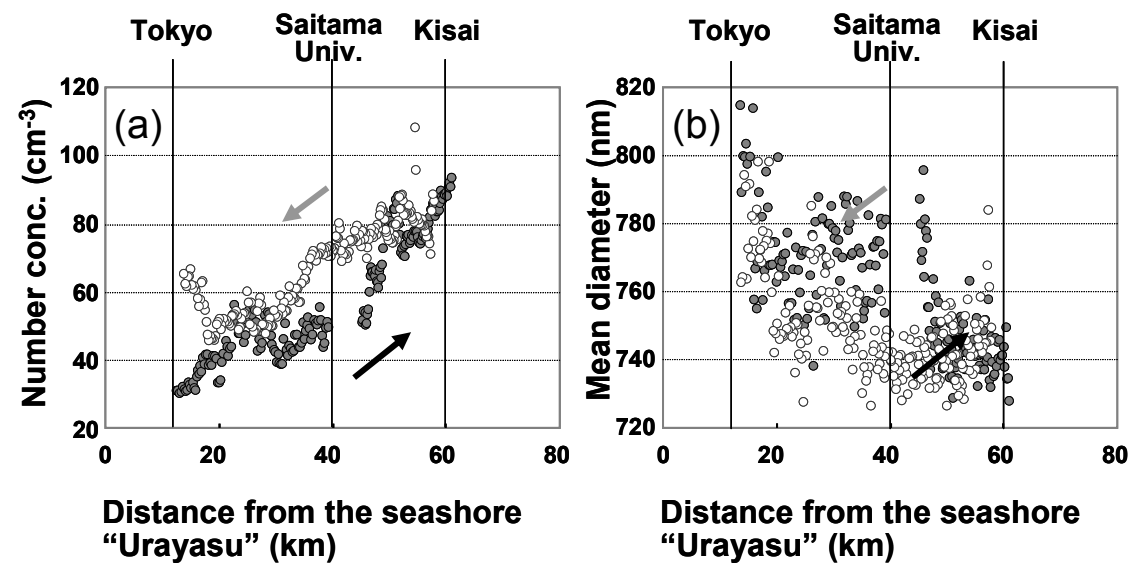

Figure 3: $\quad$ An example of spatial variation of (a) PN concentration and (b) PD between the central Tokyo and Kisai rural area, as a function of the distance from the seashore "Urayasu".

The spatial distribution of pollutants gases in this level flight showed the increased tendency of $\mathrm{O}_{3}$ concentration and the decreased tendency of $\mathrm{NOx}$ concentration was found according to the distance from Urayasu. On the other hand, the spatial distribution of ground level $\mathrm{O}_{3}$ and $\mathrm{NOx}$ are shown in Figure 4, 
which was obtained from monitoring data of the more than 200 sites. Figure 7(c) shows the spatial distribution of $\mathrm{O}_{3}$ concentration of 15:00 on July 30 2008. The $\mathrm{O}_{3}$ concentration of Saitama University and Kisai site was 69.7 and 69.2ppb each, and there were few differences in comparison with the level flight results. From comparison between level flight and ground-base measurement, it is clear that the $\mathrm{O}_{3}$ concentration measured during the level flight represents overall tendency of the South Kanto area. On the other hand, the NOx, which is assumed as ground source, showed low concentration at $600 \mathrm{~m}$ altitude, and needs attention in the absolute scale analysis except relative evaluation such as $\mathrm{NO}_{2} / \mathrm{NOx}$.
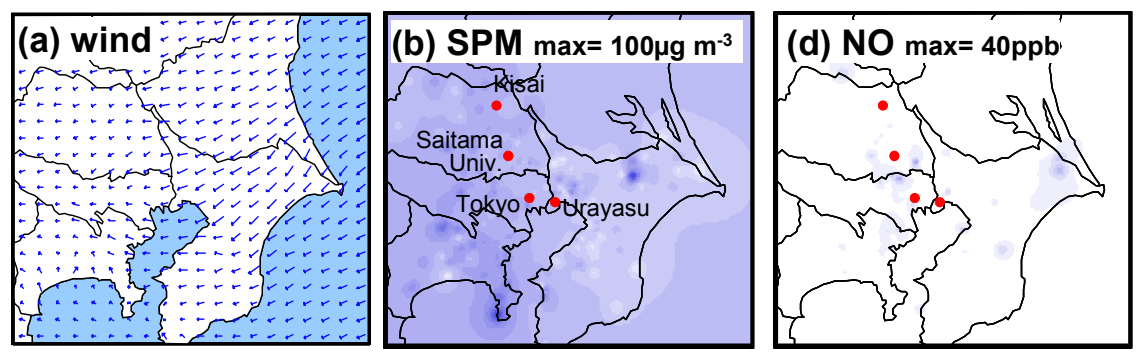

\section{Wind $\underset{\mathrm{mm} / \mathrm{s}}{\longrightarrow}$}
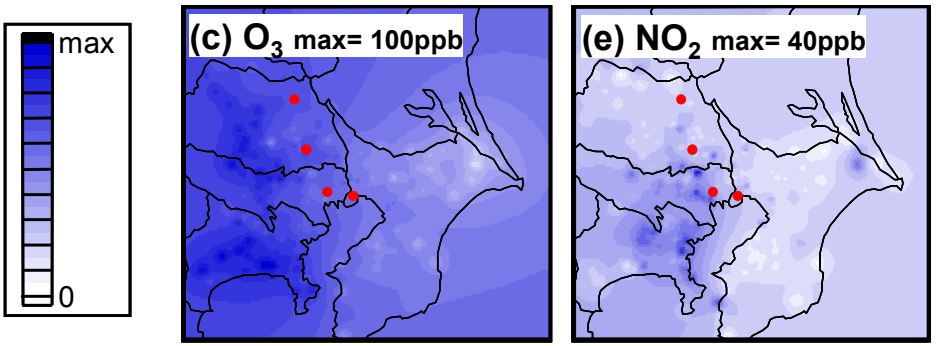

Figure 4: The spatial distribution of wind and air pollution (15:00 July 30 2008).

The temporal variation of PN and PD was seen as shown in Figure 5. It became clear that the PN concentration decreased with the local time, and the PD increased. This is considered as a variation by the mechanism of coagulation and the secondary particle condensation to the particle. The research of the nucleation is generally reported by a variation of particle less than $50 \mathrm{~nm}$. Laaksonen et al. [11] reported the nano-particle growth rate of around $1 \mathrm{~nm} \mathrm{hr}^{-1}$ from measurement in the Finnish forest sky. Liu et al. [13] showed growth rates of $2.2-19.81 \mathrm{~nm} \mathrm{hr}^{-1}$ from measurement of the Chinese city sky. According to Minoura and Takekawa [14] who observed the growth rate in a suburban of Japan, the daytime growth rate in summer was $7.9 \mathrm{~nm} \mathrm{hr}^{-1}$, however it became higher value of $14.7 \mathrm{~nm} \mathrm{hr}^{-1}$ in the evening due to enhancement of condensation effect. As shown in Figure 6b, growth rate of particle sized more than $0.5 \mu \mathrm{m}$ was $3.79 \mathrm{~nm} \mathrm{hr}^{-1}$, and it was agreed with the extent of the particle growth rate of $1-20 \mathrm{~nm} \mathrm{hr}^{-1}$ that Kulmara et al. [10] pointed out as a typical growth rate in cities. 
Kalafut-Pettibone et al. [15] observed the variation of the particle volume using APS and SMPS in Mexico City and showed the daytime increase in particle volume of $700 \mathrm{~nm}$. This particle growth rate is the first value measured in the upper PBL of the Tokyo sky. However, we should consider that this value was obtained from the partial growth of tail of the nucleation mode particle of less than $50 \mathrm{~nm}$. On the other hand, the above researcher mentioned a particle nucleation ratio of $0.01-10 \mathrm{~cm}^{-3} \mathrm{~s}^{-1}$, however negative value was obtained from this research, and the gradient of Figure 9(a) was $-0.001 \mathrm{~cm}^{-3} \mathrm{~s}^{-1}$. It is thought that this is the same reason that our observation was limited in size range of more than $500 \mathrm{~nm}$.
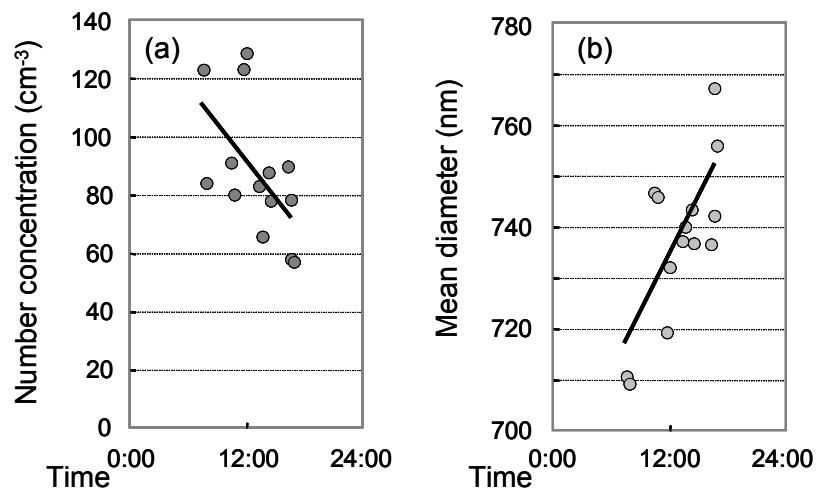

Figure 5: Temporal variation of (a) PN concentration and (b) PD averaged every each level flight. The rate of change to be provided from the gradient of the regression line is $3.79 \mathrm{~nm} \mathrm{hr}^{-1}$ and $-0.001 \mathrm{~cm}^{-3} \mathrm{~s}^{-1}$ each.

The PN concentration and the relationship with the PD showed the wellorganized distribution form as shown in Figure 6. The white circles show a particle sampled in inland area of $600 \mathrm{~m}$ altitude, and the black circles show a particle sampled in coast line area of $200 \mathrm{~m}$ altitude. As for the particle of coast line area, the distribution was inclined in larger particle in comparison with the distribution of inland particle. When the particle is assumed to be a sphere, particle volume (PV) can be displayed as the aslant axis shown in Figure 6. As a result, a volumetric change of more than 3 times was seen in the distribution of particles sampled in the inland area, whereas, a clear volumetric change was not seen in the distribution of particles sampled in the coast line. It is suggested that the particle of the coast line showed physical coagulation and separation without the volumetric change. On the other hand, the process of the volumetric increase with the condensation of the secondary particle was seen in the particle of the inland area.

The size distributions corresponding to the symbol "a" - "c" in Figure 6 are shown in Figure 7. The symbol "a" represents a distribution of the coast line particles featuring comparably high $\mathrm{PN}$ concentration in $1 \mu \mathrm{m}$ or more. The 
symbol "c" represents a distribution of the inland particles featuring high PN concentration in less than $1 \mu \mathrm{m}$. The volume increase of the particle depended on PN concentration increase of particle less than $1 \mu \mathrm{m}$ represented by the difference from "b" to "c" in Figure 7.

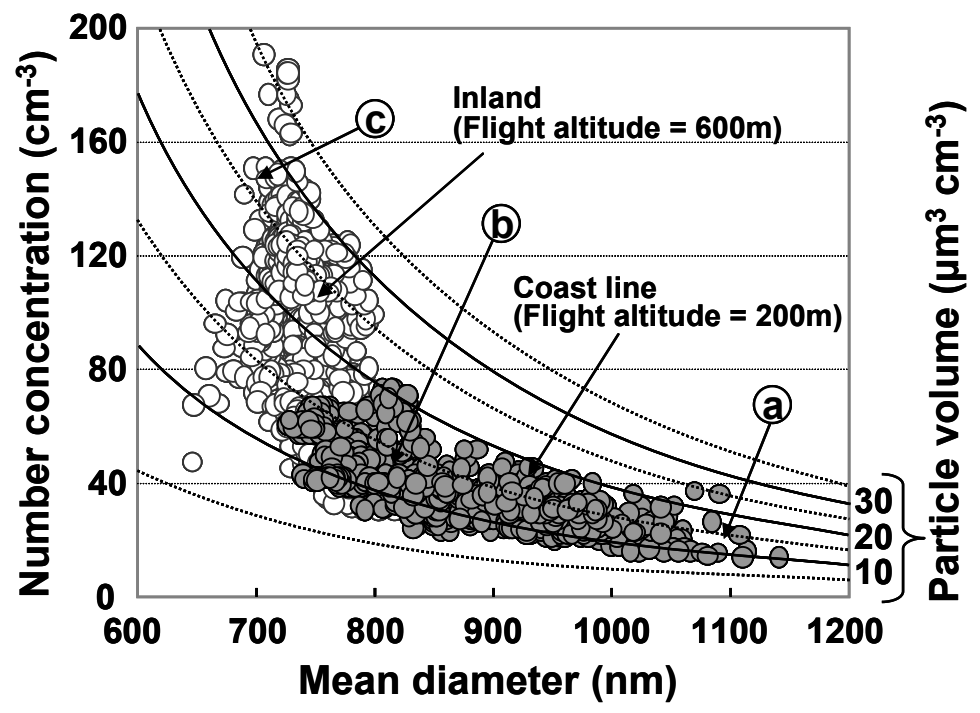

Figure 6: $\quad$ PN concentration and the relationship with PD.

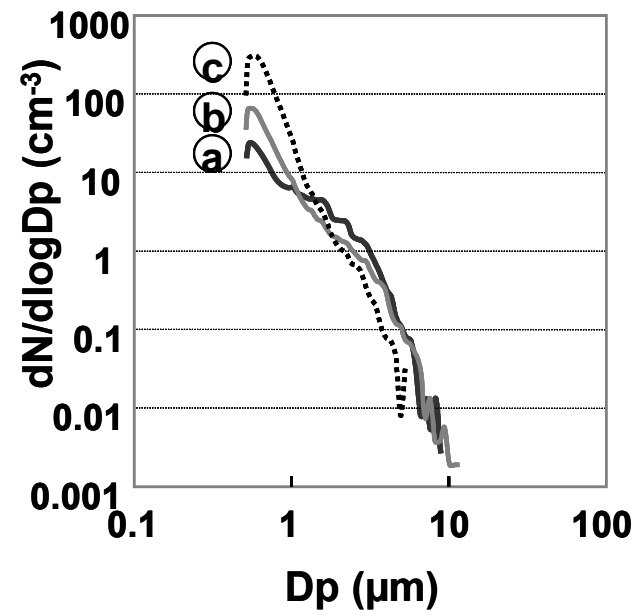

Figure 7: Typical PN size distribution in corresponding with "a"-"c" in Figure 6. (a) distribution of coast line area, (c) in inland area. 
The increment of the PV was provided as a function of the distance from the coast, and it was changed in the range of $0.1-0.4 \mu \mathrm{m}^{3} \mathrm{~cm}^{-3} \mathrm{~km}^{-1}$ by each flight. A major factor to affect the PV increase was investigated among pollutants concentration and meteorological elements. It became clear that the PV growth rate has a positive relation with the $\mathrm{NO}_{2}$ concentration, and a negative relation with ambient temperature as shown in Figure 8. The correlation coefficients with PV growth were summarized in Tables 2 and 3. Because the aircraft was not equipped with temperature/hygrometer, it was compared with the data of the ground truth stations. The only correlation coefficient of wind velocity and the temperature were shown in Table 3, because the other elements showed low absolute value of less than 0.2 .

The positive correlation with $\mathrm{NO}_{2}$ or $\mathrm{NO}_{2} / \mathrm{NOx}$ in Table 2 suggests that $\mathrm{PV}$ growth rate of the particle is high where the photochemical oxidation made progress. Hering et al. [16] reported the similar results during the POLLUMET
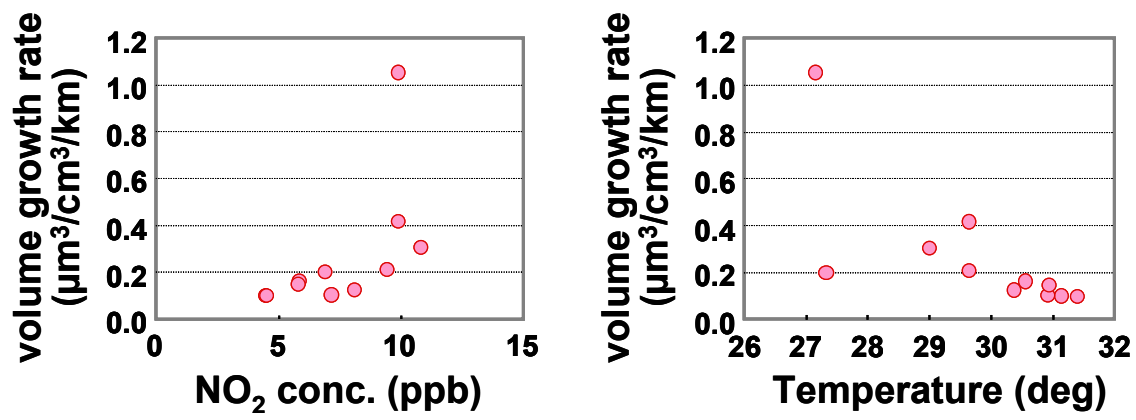

Figure 8: $\quad \mathrm{PV}$ growth rate and the relation with $\mathrm{NO}_{2}$ concentration measured inland level flight, and average temperature measured grand sites.

Table 2: Correlation coefficients with the particle volume growth rate and gases.

\begin{tabular}{|c|c|c|c|c|c|}
\hline $\begin{array}{c}\text { Observation } \\
\text { location }\end{array}$ & $\mathrm{NO}$ & $\mathrm{NO}_{2}$ & $\mathrm{NOx}$ & $\mathrm{NO}_{2} / \mathrm{NOx}$ & $\mathrm{O}_{3}$ \\
\cline { 2 - 6 } & $\mathrm{ppb}$ & $\mathrm{ppb}$ & $\mathrm{ppb}$ & & $\mathrm{ppb}$ \\
\hline Aircraft & -0.076 & 0.580 & 0.114 & 0.320 & -0.517 \\
\hline
\end{tabular}

Table 3: Correlation coefficients with the particle volume growth rate and weather.

\begin{tabular}{|c|c|c|}
\hline $\begin{array}{c}\text { Observation } \\
\text { location }\end{array}$ & Wind velocity & Temperature \\
\cline { 2 - 3 } & $\mathrm{m} \mathrm{s}^{-1}$ & degree \\
\hline Urayasu & -0.228 & -0.715 \\
\hline Tokyo & -0.394 & -0.586 \\
\hline Saitama Univ. & -0.481 & -0.656 \\
\hline Kisai & -0.532 & - \\
\hline
\end{tabular}


study. The negative correlation with the wind velocity is considered results by the dilution of the secondary particle or its precursor. As the first reason, the decline of the $\mathrm{O}_{3}$ concentration in Table 2 is considered the results that contributed to a particle formation. As the second reason, due to the activation of the convective flow, $\mathrm{O}_{3}$ was supplied from upper air and it increased the $\mathrm{O}_{3}$ concentration, as the same time, the secondary particle or its precursor was diluted and it decreased the particle volume. As for the negative correlation with the temperature, the influence by the volatilization of secondary particle is considered, and the association with the effect of convective activity mentioned above might be considered.

As for the PN concentration, the PD, and the PV, it became clear that the value changed at the rate of $0.74 \mathrm{~cm}^{-3} \mathrm{~km}^{-1},-0.48 \mathrm{~nm} \mathrm{~km}^{-1}, 0.057 \mu \mathrm{m}^{3} \mathrm{~cm}^{-3} \mathrm{~km}^{-1}$ each as a function of distance from the coast line by making a level flight to north of the inland area. As for the increase of the PV, secondary particle formation was suggested, and the increment tendency of the volume growth rates was seen in comparison with the $\mathrm{NO}_{2}$ concentration in particular.

\section{Conclusions}

A spatial variation of the particle size distribution $(0.5-10 \mu \mathrm{m})$ of the coast line area and the inland area was measured nine times in three days from July 30, 2008 by using an aircraft. During this flight, wind blew perpendicularly to the flight course and the different character of particle could be observed from the coast area to the inland area. From rawinsonde observation, the aircraft observation of whole period was carried out in the PBL.

The vertical measurement of pollutant concentration between $300 \mathrm{~m}$ and $600 \mathrm{~m}$ was carried out at two points in the inland area for every nine flights. It is cleared that the concentration of pollutants ( $\mathrm{NO}, \mathrm{NO}_{2}, \mathrm{O}_{3}$, and particle number "PN") showed approximately constant value without depending on altitude, but showed temporal and spatial variation.

The increased tendency of PN concentration and the decreased tendency of mean particle diameter (PD) were observed as we conducted the level flight to north (the deep inland area). The PN concentration and the relationship with the PD showed the well-organized distribution. As for the particle of coast line area, the distribution was inclined in larger particle. A volumetric change of more than 3 times was seen in the distribution of particles sampled in the inland area, whereas, a clear volumetric change was not seen in the distribution of particles sampled in the coast line. The increment tendency of the volume (PV) growth rates was seen in comparison with the $\mathrm{NO}_{2}$ concentration in particular. The negative correlation was seen between PV growth and ambient temperature. It is suggested that the volumetric increase with the condensation of the secondary particle accompanied by photochemical oxidation was seen in the particle of the inland area. As for the PN concentration, the PD, and the PV, it became clear that the value changed at the rate of $0.74 \mathrm{~cm}^{-3} \mathrm{~km}^{-1},-0.48 \mathrm{~nm} \mathrm{~km}^{-1}$, $0.057 \mu \mathrm{m}^{3} \mathrm{~cm}^{-3} \mathrm{~km}^{-1}$ each as a function of distance from the coast line. 


\section{Acknowledgements}

This research was commissioned by the Ministry of Economy, Trade and Industry, and as part of a collaborative research program between auto and oil industries called Japan Auto-Oil Program (JATOP) run by Japan Petroleum Energy Center.

\section{References}

[1] Vedal, S., Critical Review - Ambient particles and health: Lines that divide. Journal of the Air \& Waste Management Association 47 (5), 551581, 1997.

[2] Watson, J.G., Chow, J.C., A wintertime $\mathrm{PM}_{2.5}$ episode at the Fresno, CA supersite. Atmospheric Environment 36 (3), 465-475, 2002.

[3] Jacobson, M.Z., Analysis of aerosol interactions with numerical techniques for solving coagulation, nucleatin, condensation, dissolution, and reversible chemistry among multiple size distributions. Journal of Geophysical Research 107, AAC 2-1-AAC 2-23, doi: 10.1029/2001JD002044, 2002.

[4] Minoura, H., Takahashi, K., Chow, J.C., Watson, J.G., Multi-year trend in fine and coarse particle mass, carbon, and ions in downtown Tokyo, Japan. Atmospheric Environment 40, 2478-2487, 2006.

[5] Aikawa, M., Ohara, T., Hiraki, T., Oishi O., Tsuji, A., Yamagami M., Murano K., Mukai H., Significant geographic gradients in particulate sulfate over Japan determined from multiple-site measurements and a chemical transport model: Impacts of transboundary pollution from the Asian continent. Atmospheric Environment 44, 381-391, 2010.

[6] Weber, R.J., Sullivan, A.P., Peltier, R.E., Russell, A., Yan, B., Zheng, M., Gouw, J., Warneke, C., Brock, C., Holloway, J.S., Atlas, E.L., Edgerton, E., A study of secondary organic aerosol formation in the anthropogenicinfluenced southeastern United States. Journal of Geophysical Research, 112, D13302, doi: 10.1029/2007JD008408, 2007.

[7] Yin, J., Harrison, R.M., Chen, Q., Rutter, A., Schauer, J.J., Source apportionment of fine particles at urban background and rural sites in the UK atmosphere. Atmospheric Environment 44, 841-851, 2010.

[8] Chen, J., Ying, Q., Kleeman, M.J., Source apportionment of wintertime secondary organic aerosol during the California regional $\mathrm{PM}_{10} / \mathrm{PM}_{2.5}$ air quality study. Atmospheric Environment 44, 1331-1340, 2010.

[9] Kim, E., Turkiewicz, K., Zulawnick, S.A., Magliano, K.L., Source of fine particles in the South Coast area, California. Atmospheric Environment 44, 3095-3100, 2010.

[10] Kulmala, M., Vehkamäki, H, Petäjä, T., Dal Maso, M., Lauri, A., Kerminen, V.-M., Brirmili, W., McMurry, P.H., Formation and growth rates of ultrafine atmospheric particles: a review of observation. Aerosol Science, 35, 143-176, 2004.

[11] Laaksonen, A., Kulmala, M., O’Dowd, C.D., Joutsensaari, J., Vaattovaara, P., Mikkonen, S., Lehtinen, K.E.J., Sogacheva, L., Dal Maso, M., Aalto, P., 
Petäjä, T., Sogachev, A., Yoon, Y.J., Lihavainen, H., Nilsson, D., Facchini, M.C., Cavalli, F., Fuzzi, S., Hoffmann, T., Arnold, F., Hanke, M., Sellegri, K., Umann, B., Junkermann, W., Coe, H., Allan, J.D., Alfarra, M.R., Worsnop, D.R., Riekkola, M.-L., HyötylUainen, T., Viisanen, Y., The role of VOC oxidation products in continental new particle formation. Atmospheric Chemistry and Physics, 8, 2657-2665, 2008.

[12] Wang, W., Ma, J., Hatakeyama, S., Liu, X., Chen, Y., Takami, A., Ren, L., Geng, C., Aircraft measurement of vertical ultrafine particles profiles over Northern China coastal areas during dust storms in 2006. Atmospheric Environment 42, 5715-5720, 2008.

[13] Liu, S., Hu, M., Wu, Z., Wehner, B., Wiedensohler, A., Cheng, Y., Aerosol number size distribution and new particle formation at a rural/coastal site in Pearl River Delta of China. Atmospheric Environment 42, 6275-6283, 2008.

[14] Minoura, H. Takekawa, H., Observation of number concentrations of atmospheric aerosols and analysis of nanoparticle behavior at an urban background area in Japan. Atmospheric Environment 39, 5806-5816, 2005.

[15] Kalafut-Pettibone, A.J., Wang, J., Eichinger, W.E., Clarke, A., Vay, S.A., Blake, D.R., Stanier, C.O., Size-resolved aerosol emission factors and new particle formation/growth activity occurring in Mexico City during the MILAGRO 2006 Campaign. Atmospheric Chemistry and Physics Discussions, 11, 6651-6705, 2011.

[16] Hering, A.M., Staehelin, J., Baltensperger, U., Prévôt, A.S.H., Kok, G.L., Schillawski, R.D., Waldvogel, A., Airbone measurement of atmospheric aerosol particles and trace gases during photosmog episodes over the Swiss plateau and the southern pre-alpine region. Atmospheric Environment 32, 3381-3392, 1998. 